\title{
Heterosis Studies for Earliness and Yield Related Traits in Ridge Gourd [Luffa Acutangula (L.) Roxb.]
}

\author{
K. Muthaiah ${ }^{1 *}$, V.D. Gasti ${ }^{2}$, Sanganamoni Mallesh ${ }^{3}$ and Kattula Nagaraju ${ }^{1}$ \\ ${ }^{1}$ ICAR-Division of Vegetable Crops, Indian Institute of Horticultural Research, \\ Hessaraghatta, Bengaluru, 560 089, Karnataka, India \\ ${ }^{2}$ Department of Vegetable Science, Kittur Rani Channamma College of Horticulture, \\ Arabhavi, University of Horticultural Sciences, Bagalkot- 587 103, Karnataka, India \\ ${ }^{3}$ Department of Vegetable Science, College of Horticulture, University of Horticultural Sciences, \\ Bagalkot- 587 104, Karnataka, India \\ *Corresponding author
}

\section{A B S T R A C T}

Keywords

Ridge gourd, Genetic architecture, Heterosis, Earliness and Yield.

Article Info

Accepted: 26 May 2017 Available Online: 10 June 2017
The present study was carried out for development of hybrids in ridge gourd for earliness and yield traits. Twenty eight crosses were developed through half diallel fashion. Evaluated the crosses and along with their parents in Randomized block design (RBD). Significant differences found in the analysis of variance for early and yield related traits which indicates enormous genetic variability present in the ridge gourd. The magnitude of heterosis was found in desirable direction for early and yield traits viz., days to first female flowering is recorded in the cross DMRG$25 \times$ DMRG-1 (-9.50\%), for nodes up to first female flowering in the cross DMRG-25 $\times$ Arka Sumeet (-16.67\%), for per cent fruit set in the cross DMRG-25 $\times$ Arka Sumeet $(36.21 \%$ ), for number of fruit per vine in the cross DMRG-25 $\times$ DMRG-44 (29.51\%), for average fruit weight in (45.95\%).

\section{Introduction}

Ridge gourd [Luffa acutangula (L.) Roxb.] Belongs to genus Luffa of Cucurbitaceae family. Ridge gourd also called as Chinese okra, angled gourd and ribbed gourd and has chromosome number $2 \mathrm{n}=26$, and is native to India. Tender fruits are green in colour, which are used in soups and curries or as a cooked vegetable. Fruit contain edible protein $(82 \%)$, moisture $92.5 \mathrm{~g}$, protein $0.5 \mathrm{~g}$, fat $0.5 \mathrm{~g}$, carbohydrate $3.4 \mathrm{~g}$, energy $17 \mathrm{k}$ cal, calcium $18 \mathrm{mg}$, vitamin C $5 \mathrm{~m} \mathrm{~g}$, riboflavin $0.01 \mathrm{mg}$, phosphorous $26 \mathrm{mg}$, iron $0.5 \mathrm{mg}$ and carotene
$33 \mathrm{mg}$ (Sheshadri and Parthasarthy, 1980) per $100 \mathrm{~g}$ of edible portion. Besides their use as vegetables, it is also used for various purposes. The fiber obtained from the mature dry fruit is used in industry for filters of various sorts, good pot holders, Table mats, bath room mats, slipper and shoe soles. The fiber is also proved to be a good insulator for various purposes. Sometimes the dry fruits which gave good storability are used for ornamental purposes also. It is emetic and traditionally used for the treatment of stomach 
ailment and fever (Chakravarthy, 1959). Ridge gourd being a monoecious and crosspollinated crop, it exhibits considerable heterozygosity in population and does not suffer much due to inbreeding depression, because heterozygosity has been balanced due to primitive form of hermaphrodite flower. Crop improvement depends upon genetic architecture of yield traits and magnitude of positive heterosis towards the yield attribute traits. Thus, provides ample scope for utilization of hybrid vigour on commercial scale. The possible exploitation of heterosis work has been taken up by several research centres. This wide range of genetic architecture in plant for early and yield related trsits and also produce large number of hybrid seed at reasonable cost, very little work has been done to exploit the hybrid vigour in this crop. Heterosis breeding is the one of potential tool for exploitation of yield and yield contributing traits. Hence, an attempt was made to study the heterosis in different crosses over better parent, the best parent and the commercial check to develop and identify the suitable best performing hybrids.

\section{Materials and Methods}

The present investigation was undertaken at Department of Vegetable Science, K.R.C. College of Horticulture, Arabhavi, University of Horticultural Sciences, Bagalkot during kharif and rabi, 2014-2015. Experimental material consists of eight parents viz; DMRG36, DMRG-25, KRCCH-1, DMRG-22, Arka Sumeet, DMRG-1, DMRG-15 and DMRG44. 28 hybrids were developed through half diallel mating design during kharif 2014.

All the 28 hybrids along with their parents were evaluated in Randomised Block Design with two replications during rabi 2014-2015. The observations were recorded on tagged selected five plants in each replication and data recorded for various traits viz., earliness and yield attributing traits of parents and hybrids. Heterosis was calculated as percentage of $F_{1}$ performance in the favourable direction over better parent, best parent and commercial check.

\section{Results and Discussion}

The estimates of mean sum of squares due to parents showed significant differences for all the characters, except days to first female flower appearance, nodes upto first female flower, average fruit weight and per cent fruit set and it, indicating the presence of sufficient variability among the parents.

The estimates of mean sum of squares due to crosses were highly significant for all the characters among 28 crosses, this indicates enormous amount of variability present among the hybrids under studied (Table 1). Per se performance and range (mean performance) of parents and crosses for various heterotic effects as well as the heterotic crosses identified on the basis of earliness and yield parameters are presented in the (Tables 2 and 3). The heterotic responses of F1 hybrids over better parent (BTP) and best parent (BP) for eight characters significant for both positive and negative direction are presented in the(Tables 2 and 3).

\section{Early parameters}

Negative heterosis desirable for earliness, for days to first female flower appearance, maximum and significant negative heterosis over better parent was observed in the cross DMRG-25 x DMRG-1 (-9.50\%) followed by DMRG-22 x DMRG-1 (-8.25\%) and DMRG36 x DMRG-22 (-4.68\%). Negative heterosis with reference to days to female flower appearance was also reported by Rao and Rao (2002) in ridge gourd. The cross DMRG-25 x DMRG-1 (-9.50\%) significant negative heterosis over the best parent is low, 
compared with earlier reported by Jadhav et al., 2009 in the bitter gourd. For nodes upto first female flower appearance, maximum and significantly negative heterosis over the better parent was observed in the cross DMRG-25 $\mathrm{x}$ Arka Sumeet (-16.67\%) followed by DMRG$36 \times$ DMRG-25 (-15.12\%) and the cross DMRG-25 $\times$ DMRG-1 exhibited significant and negative heterosis over the commercial check $(-11.49 \%)$.

Similar findings were reported by Shaha and Kale (2003b), Narasannavar et al., (2014) and Shivanand (2014). The cross DMRG-22 x DMRG-1 (-37.04\%) significant negative heterosis over the best parent is high, compared with earlier reported by Jadhav et $a l ., 2009$ in the bitter gourd.

\section{Yield parameters}

For sex ratio maximum and significantly positive heterosis over the better parent was observed in the cross DMRG-25 x Arka Sumeet $(54.51 \%)$ followed by DMRG-25 x DMRG-44 (23.02\%), positive heterosis for this character was also reported by Thangamani et al., (2011) in bitter gourd. The cross DMRG-36x DMRG-22 (22.45\%) significant positive heterosis over the best parent is high, compared with earlier reported by Jadhav et al., (2009) in the bitter gourd. For per cent fruit set, the cross DMRG-25 $\times$ Arka Sumeet (36.21\%) exhibited the maximum and positive heterosis which is high compared to 19.44 per cent reported by Kallimani (2004) in bitter gourd and Narasannavar et al., (2014) in ridge gourd.

Table.1 Analysis of variance with respect of eight characters in ridge gourd

\begin{tabular}{|c|c|c|c|c|c|c|}
\hline \multirow[b]{2}{*}{ Source of variation } & \multicolumn{6}{|c|}{ Mean sum of square } \\
\hline & Replication & Treatments & Parents & Hybrids & $\begin{array}{l}\text { Parents Vs. } \\
\text { Hybrids }\end{array}$ & Error \\
\hline Degree of freedom & 1 & 35 & 7 & 27 & 1 & 35 \\
\hline \multicolumn{7}{|l|}{ Characters } \\
\hline \multicolumn{7}{|l|}{ Early parameters } \\
\hline Days to first female flowering & 0.46 & $5.34 * *$ & 0.94 & $6.44 * *$ & $6.19 *$ & 1.50 \\
\hline Nodes to first male flowering & 0.37 & $0.92 * *$ & $0.44 *$ & $1.05^{* *}$ & 0.66 & 0.18 \\
\hline Nodes to first female flowering & 0.027 & $0.82 *$ & 0.45 & $0.91 * *$ & 0.99 & 0.36 \\
\hline \multicolumn{7}{|l|}{ Yield parameters } \\
\hline Sex Ratio (Male:Female) & $74.11 * *$ & $18.38 * *$ & $17.45 *$ & $19.09 * *$ & 5.66 & 5.53 \\
\hline Per cent fruit set $(\%)$ & 7.67 & $180.74 * *$ & 49.56 & $221.37 * *$ & 2.10 & 27.00 \\
\hline Number of fruit per vine $(\mathrm{kg})$ & 0.47 & $3.36^{* *}$ & $2.36 * *$ & $3.75^{* *}$ & 0.19 & 0.41 \\
\hline Fruit diameter(mm) & 0.00 & $21.09 * *$ & 4.41 & $26.07 * *$ & 3.71 & 2.59 \\
\hline Average fruit weight $(\mathrm{g})$ & $1436.39 * *$ & $396.07 * *$ & 117.62 & $466.20 * *$ & 451.62 & 125.88 \\
\hline
\end{tabular}


Table.2 Top three hybrids identified based on heterosis for earliness and Yield parameters in ridge gourd

\begin{tabular}{|c|c|c|c|c|c|}
\hline \multirow[t]{2}{*}{ Parameters } & \multicolumn{2}{|c|}{$\begin{array}{l}\text { No. of hybrids having } \\
\text { significant heterotic } \\
\text { effects(based on } \\
\text { better, best and } \\
\text { standard heterosis) } \\
\end{array}$} & \multicolumn{3}{|c|}{ Best three hybrids based on } \\
\hline & $+\mathrm{ve}$ & -ve & BP & BTP & $\mathbf{C C}$ \\
\hline \multicolumn{6}{|l|}{ Early parameters } \\
\hline \multirow{3}{*}{$\begin{array}{l}\text { Days to first female } \\
\text { flowering }\end{array}$} & 10 & 06 & DMRG-25 × DMRG-1(-9.50\%) & DMRG-25 × DMRG-1(-9.50\%) & DMRG-25 × DMRG-1(-11.49\%) \\
\hline & 04 & 07 & DMRG-22 × DMRG-1 (-8.25\%) & DMRG-36× DMRG-22 (-8.25\%) & DMRG-36× DMRG-22 (-9.27\%) \\
\hline & 02 & 09 & DMRG-36× DMRG-22 (-4.68\%) & DMRG-36 $\times$ Arka Sumeet $(-7.25 \%)$ & DMRG-36 $\times$ Arka Sumeet $(-9.29 \%)$ \\
\hline \multirow{3}{*}{$\begin{array}{l}\text { Nodes upto first } \\
\text { male flowering }\end{array}$} & 9 & 17 & DMRG-22 × DMRG-1(-37.04\%) & DMRG-22× DMRG-1(-37.04\%) & DMRG-22 × DMRG-1(-20.93\%) \\
\hline & 3 & 20 & DMRG-36× DMRG-1 (-31.48\%) & DMRG-36× DMRG-25 (-33.33\%) & DMRG-36× DMRG-22 (-18.60\%) \\
\hline & 11 & 12 & DMRG-25× DMRG-22 (-30.61\%) & DMRG-36× DMRG-1 (-31.48\%) & DMRG-36× DMRG-25 (-16.28\%) \\
\hline \multirow{3}{*}{$\begin{array}{l}\text { Nodes up to first } \\
\text { female flowering }\end{array}$} & 11 & 10 & DMRG-25 $\times$ Arka Sumeet $(-16.67 \%)$ & DMRG-36 × DMRG-25 (-18.89\%) & DMRG-25 × DMRG-1 (-11.49\%) \\
\hline & 05 & 14 & DMRG-36× DMRG-25 (-15.12\%) & DMRG-25 $\times$ Arka Sumeet $(-16.67 \%)$ & DMRG-36× DMRG-25 (-8.75\%) \\
\hline & 15 & 07 & DMRG-36× DMRG-15 (-11.76\%) & DMRG-36× DMRG-22 (-11.11\%) & - \\
\hline \multicolumn{6}{|l|}{ Yield parameters } \\
\hline \multirow{3}{*}{ Sex ratio } & 08 & 19 & DMRG-25× Arka Sumeet (54.51\%) & DMRG-36 ×DMRG-22 (22.45\%) & DMRG-25×DMRG-1 (36.20\%) \\
\hline & 06 & 22 & DMRG-25 × DMRG-44 (23.02\%) & DMRG-25 ×DMRG-22 (14.22\%) & DMRG-36 ×Arka Sumeet $(29.85 \%)$ \\
\hline & 06 & 21 & DMRG-36× DMRG-22 (23.01\%) & DMRG-22× DMRG-1 (12.07\%) & DMRG-25× Arka Sumeet $(26.80 \%)$ \\
\hline \multirow{3}{*}{ Per cent fruit set } & 05 & 14 & DMRG-25× Arka Sumeet (36.21\%) & DMRG-25 × DMRG-1 (29.93\%) & DMRG-25 × DMRG-1 (36.20\%) \\
\hline & 05 & 18 & DMRG-25× DMRG-1 (31.54\%) & DMRG-36 × ArkaSumeet $(23.88 \%)$ & DMRG-36 × ArkaSumeet $(29.85 \%)$ \\
\hline & 06 & 16 & DMRG-36 × Arka Sumeet $(25.37 \%)$ & DMRG-25 × Arka Sumeet $(20.96 \%)$ & DMRG-25 × Arka Sumeet $(26.80 \%)$ \\
\hline \multirow{3}{*}{$\begin{array}{l}\text { Number of fruit per } \\
\text { vine }\end{array}$} & 09 & 19 & DMRG-25 × DMRG-44 (29.51\%) & DMRG-25 $\times$ Arka Sumeet $(12.50 \%)$ & DMRG-25 $\times$ Arka Sumeet $(18.41 \%)$ \\
\hline & 05 & 21 & DMRG-25 × DMRG-1 $(24.66 \%)$ & DMRG-25 × DMRG-1 (10.98\%) & DMRG-25 × DMRG-1 (16.82\%) \\
\hline & 07 & 19 & DMRG-25 × Arka Sumeet $(18.27 \%)$ & DMRG-25 × DMRG-22 (9.76\%) & DMRG-25 × DMRG-22 (15.53\%) \\
\hline \multirow{3}{*}{ Fruit diameter } & & & DMRG-25 × Arka Sumeet $(24.72 \%)$ & DMRG-25 × ArkaSumeet $(20.62 \%)$ & DMRG-25 × Arka Sumeet $(24.20 \%)$ \\
\hline & 07 & $\begin{array}{l}10 \\
15\end{array}$ & DMRG-25 × DMRG-1 (19.86\%) & DMRG-25 × DMRG-1 (15.51\%) & DMRG-25 × DMRG-1 (18.95\%) \\
\hline & 00 & 15 & - & - & - \\
\hline \multirow{2}{*}{$\begin{array}{l}\text { Average fruit } \\
\text { weight }\end{array}$} & 03 & 01 & DMRG-25 × Arka Sumeet (45.95\%) & DMRG-25 × Arka Sumeet $(42.47 \%)$ & DMRG-25 × Arka Sumeet $(48.84 \%)$ \\
\hline & 01 & 03 & Arka Sumeet $\times$ DMRG-15 $(26.60 \%)$ & - & - \\
\hline
\end{tabular}

*And $* *$ indicate significance of values at $\mathrm{p}=0.05$ and $\mathrm{p}=0.01$, respectively 
Table.3 Range and heterosis for earliness and yield parameters in ridge gourd

\begin{tabular}{|c|c|c|c|c|c|}
\hline \multirow[t]{2}{*}{ Per se performance } & \multicolumn{2}{|l|}{ Range } & \multicolumn{3}{|l|}{ Heterosis $(\%)$} \\
\hline & Parents & Crosses & BTP & $\mathrm{BP}$ & $\mathrm{CC}$ \\
\hline \multicolumn{6}{|l|}{ Early parameter } \\
\hline Days to first female flowering & 38.20 to 40.00 & 36.20 to 41.80 & -9.50 to 8.86 & -9.50 to 4.50 & 11.49 to 5.13 \\
\hline Nodes up to first male flowering & 4.10 to 5.40 & 3.40 to 5.70 & -37.04 to 16.33 & -37.04 to 9.26 & 20.93 to 37.21 \\
\hline Nodes up to first female flowering & 7.70 to 9.00 & 7.30 to 10.10 & -16.67 to 18.75 & -18.89 to 6.67 & 11.49 to 20.00 \\
\hline \multicolumn{6}{|l|}{ Yield parameter } \\
\hline Sex ratio & 5.16 to 12.09 & 4.36 to 14.81 & -63.95 to 54.15 & -63.95 to 22.45 & 60.05 to 35.19 \\
\hline Per cent fruit set & 39.23 to 52.12 & 26.10 to 67.73 & -43.62 to 36.21 & -49.93 to 29.93 & 47.51 to 36.20 \\
\hline Number of fruit per vine & 5.10 to 8.20 & 4.20 to 9.22 & -48.78 to 29.51 & 48.78 to 12.50 & 46.08 to 18.41 \\
\hline Fruit diameter & 32.31 to 37.23 & 30.34 to 44.90 & -16.00 to 24.75 & 16.00 to 20.62 & 15.12 to 24.20 \\
\hline Average fruit weight & 56.10 to 86.20 & 52.98 to 119.25 & -35.15 to 45.95 & 36.70 to 42.47 & 33.87 to 48.84 \\
\hline
\end{tabular}

BTP: Heterosis over better parent BP: Heterosis over best parent CC: Hesterosis commercial check

For number of fruit per vine, the maximum and positive significant heterosis was observed in the cross DMRG-25 $\times$ DMRG-44 (29.51\%) over better parent and DMRG-25 $\times$ Arka Sumeet $(18.41 \%)$ shown positive significant heterosis over the commercial check. Similar findings were made for significant and positive heterosis over better parent by Shaha and Kale (2003a) and Narasannavar et al., (2014) and over commercial check by Mole et al., (2001) in ridge gourd. The cross DMRG-25 x Arka Sumeet $(12.50 \%)$ significant negative heterosis over the best parent is low, compared with earliar reported by Jahan et al., (2012) in the pumpkin. For average fruit weight, the cross DMRG-25 $\times$ Arka Sumeet $(45.95 \%)$ exhibited maximum heterosis over better parent, which is very high compared to 19.99 per cent reported by Shaha and Kale (2003a) and Narasannavar et al., (2014) in ridge gourd, for average fruit weight, the cross DMRG-25 × Arka Sumeet also exhibited maximum and significant heterosis of 48.84 per cent over commercial check and is very high compared to 10.74 per cent in sponge gourd as reported by Naliyadhara et al., (2007).

For fruit diameter, the cross DMRG-36 $\times$ Arka Sumeet showed maximum heterosis $(24.72 \%)$ over better parent compared with the results of 24.66 per cent as reported by Hedau and Sirohi (2004a) and Narasannavar et al., (2014) in ridge gourd. The cross DMRG-25 × Arka Sumeet exhibited maximum and positive heterosis of 24.20 per cent over commercial check and is high compared to 18.56 per cent reported by Hedau and Sirohi (2004a). The cross DMRG-25 $\mathrm{x}$ Arka Sumeet $(20.62 \%)$ significant negative heterosis over the best parent is high, compared with earlier reported by Jadhav et al., 2009 in the bitter gourd. The hybrid DMRG-25 $\times$ DMRG-1 was selected for number of fruit per vine and had high total yield of 4.83 t/ha yielding ability compared to $3.07 \mathrm{t} / \mathrm{ha}$ yield of commercial check with 55.56 per cent standard heterosis. Its performance is attributed by significant standard heterosis observed in the desirable direction for nodes upto first male flowering, per cent fruit set and fruit diameter.

The hybrid DMRG-25 $\times$ DMRG-44 was selected for number of fruit per vine and its total yield of 2.73 t/ha with 18.41 per cent standard heterosis. High magnitude of heterosis observed in these hybrids for number of fruit per vine. These hybrids also attributed by significant heterosis observed over commercial check in desirable direction for sex ratio, per cent fruit set and fruit diameter.

\section{Acknowledgement}

The authors would like to acknowledge Associate Professor Department of Vegetable Science, K.R.C. College of Horticulture, Arabhavi, University of Horticultural Sciences, Bagalkot for help in conducting the research successfully, technical support during the research work. 


\section{Author contributions}

K. Muthaiah - Design of the research programme, crossing work, data collection, data analysis and interpretation, critical revision of the article, final approval of the version to be published and acted as corresponding author.

V.D. Gasti - Helped during data analysis Sanganamoni Mallesh - Helped during research article writing

Kattula Nagaraju - Critical revision of the research article

\section{References}

Chakravarthy, M. L., 1959, Monograph of Indian cucurbitaceous (Taxonomy and Distribution). Records of the Botanical distribution of India, 17: 6-7.

Hedau, N.K. and Sirohi, P.S. 2004.Heterosis studies in ridge gourd. Indian J. Hort. 61(3): 236-239.

Jadhav, K.A., Garad, B.V., Dahmal, S. S., Kashirsagar, D.B., Patil, B.T. and Shinde, K.G. 2009.Heterosis in bitter gourd (Momordica charantiaL.).Agric. Sci. Digest. 29 (1): 7-11.

Jahan, T. A., Islam, A., Rasul, M. G., Main, M. and Haque, M. M., 2012, Heterosis of qualitative and quantitative characters in pumpkin (Cucurbita moschata Duch. Ex. Poir.). African J. Food Agri. Nutrition Dev., 12 (3): 6186-6199.

Kallimani, M.R.2004.Development of $F_{1}$ hybrids in bitter gourd (Momordica charantia L.).M.Sc. (Hort.) Thesis, Univ. Agric. Sci., Dharwad. M. Sc. Thesis, Univ. Hort. Sci.,Bagalkot.

Mole, T.J., Nirmaladevi, S., Rajan, S. and
Sadhankumar, P.B. 2001. Heterosis and combining ability in ridge gourd ( Luffa acutangula L. Roxb.).Veg. Sci.28 (2): 156-167.

Naliyadhara, M.V., Dhaduk, L.K., Barad, A.V., Purohit, V.L. and Vachhani, J.H., 2007. Heterosis for fruit yield and its components in sponge gourd (Luffa cylindrica (Roem.) L.). Natnl. J. Pl. Improv.9 (2): 132-135.

Narasannar, A.R., Gasti, V.D., Shantappa, T., Mulge, R., Allolli, T.B. and Thammaiah, N. 2014. Heterosis studies in ridge gourd (Luffa acutangula (L.) Roxb.).27 (1): 4751.

Rao, B.N. and Rao, P.V. 2002. Heterosis in ridge gourd (Luffa acutangula (Roxb.) L.). J. Res. ANGRAU.30 (1): 11-18.

Shaha, S. R.and Kale,P. N., 2003a,Heterosis studies in ridge gourd. J. Maharashtra Agric. Univ., 28(3): 334-336.

Shaha, S.R. and Kale, P.N. (2003b). Diallel analysis for combining ability in ridge gourd.J. Maharastra Agric. Univ. 28 (3): 252-254.

Sheshadri, V. S. and Parthasarthy, U. A., 1980, Cucurbits in vegetable crops In: Bose,

Shivanand, B. K., 2014, Physiological basis for heterosis in ridge gourd (Luffa acutangula L.)

T. K., Kabir, J., Maity, T. K., Parthasarthy, V. A. and Som, M. G. (Eds.)

Thangamani, C., Pugalendhi, L., Sumathi, T., Kavita, C. and Rajashree, V. 2011. Estimation of combining ability and heterosis for yield and quality characters in bitter gourd (Momordica charantia L.). Electron. J. Pl. Breed.2 (1): 62-66. Veg. crops, pp. 496-497.

\section{How to cite this article:}

Muthaiah K., V. D. Gasti, Sanganamoni Mallesh and Kattula Nagaraju. 2017. Heterosis Studies for Earliness and Yield Related Traits in Ridge Gourd [Luffa Acutangula (L.) Roxb.]. Int.J.Curr.Microbiol.App.Sci. 6(6): 2656-2661. doi: https://doi.org/10.20546/ijcmas.2017.606.316 